\title{
Poslovni turizem ali kongresna dejavnost
}

\author{
Marijana Sikošek \\ UP Fakulteta za turistične študije - Turistica \\ marijana.sikosek@fts.upr.si
}

\section{Uvod}

Različni motivi za potovanje generirajo obisk turistične destinacije in s tem pojav različnih oblik oz. zvrsti turizma. Čeprav so motivi za turistični obisk destinacije lahko precej različni, se percepcija turističnega obiska večinoma navezuje na koncept koriščenja prostega časa posameznika. Zato pri opredeljevanju motivov precej redkeje pomislimo na to, da je vzvod za obisk destinacije lahko tudi poslovne narave. Turizem je konceptualno povezan s posameznikovim prostim časom. Prav zaradi ločitve časa posameznika na čas, ki ga nameni delu, od časa, ki ga ne nameni službenim dejavnostim, lahko govorimo o pojavu koncepta turizma, ki ga zato pojmovno najpogosteje povezujemo s preživljanjem prostega časa in potovanjem oseb iz kraja njihovega stalnega bivališča (Burkart in Medlik, 1992). Poslovni turizem pa je koncept, ki se razlikuje od koncepta prostočasnega turizma, saj temelji na aktivnostih, povezanih s potovanji v službenem času. Pri opredeljevanju koncepta poslovnega turizma je potrebno opozoriti tudi na to, da o njem najpogosteje govorimo v povezavi z obiskom oz. udeležbo posameznikov v različnih vrstah poslovnih prireditev, ki so povezane z njihovim delom. 
V nadaljevanju najprej pojasnjujemo koncept poslovnega turizma $\mathrm{v}$ odnosu do prostočasnega turizma, nadaljujemo $\mathrm{z}$ opredelitvami poslovnega turizma in različnih oblik poslovnih srečanj, zaključujemo pa s posebnostmi te tematske oblike turizma v svetu in v Sloveniji.

\section{Opredelitev koncepta poslovnega turizma, kongresne dejavnosti in kongresnega turizma}

Swarbrooke in S. Horner (2001) menita, da je poslovni turizem širok pojem, na katerega se navezujejo pomensko ožji koncepti. Nujno pa je že na začetku opozoriti na precej nedorečeno in razdrobljeno terminologijo, kar zagotovo izhaja iz dejstva, da je na področju poslovnih prireditev zaslediti več različnih pojavnih oblik (Rogers, 1998; Ladkin, 2002; Sikošek, 2012).

Pri opredelitvi koncepta bomo izhajali iz definicije poslovnega turista, ki vsebuje osnovni namen potovanja posameznika in ki ga je med prvimi opredelil Rogers (1998, str. 19), in sicer kot »osebo, katere osrednji namen potovanja je udeležba v dejavnostih ali dogodkih, povezanih z njegovim delom ali delovnimi interesi«. Gre torej za osebo, ki primarno iz poslovnih razlogov potuje na različne poslovne dogodke in opravlja poslovna potovanja. Glede na obseg oz. množičnost udeležbe posameznikov v poslovnem potovanju združuje dve pojavni obliki: individualni poslovni turizem in skupinski poslovni turizem. Med prvimi je individualno obliko definiral Rogers (1998, str. 19) in jo poimenoval individual business travel ali corporate travel, poslovnega popotnika pa business traveller. Swarbrooke in S. Horner (2001, str. 3) sta jo opredelila kot business travel ali individual general business trip. Razumemo ga kot potovanje ene osebe s poslovnim namenom, vključuje pa poslovna potovanja zaradi svetovanja, prodaje ipd., na primer potovanje trgovskega potnika. Druga pojavna oblika poslovnega turizma vključuje potovanje več oseb s poslovnim namenom na isti kraj zaradi udeležbe na poslovnem srečanju (prireditvi), kar imenujemo skupinski poslovni turizem. Ta obsega poslovna potovanja, ki se jih naenkrat udeleži večje število oseb, kot so konference, kongresi, motivacijska potovanja, poslovna srečanja, razstave ter vladna srečanja, in je v literaturi najpogosteje imenovan $\mathrm{z}$ akronimom MICE, vendar najdemo tudi druge izraze, kar pojasnjujemo v nadaljevanju.

Na sliki 7.1 je prikazana umeščenost koncepta poslovnega turizma 
Turizem

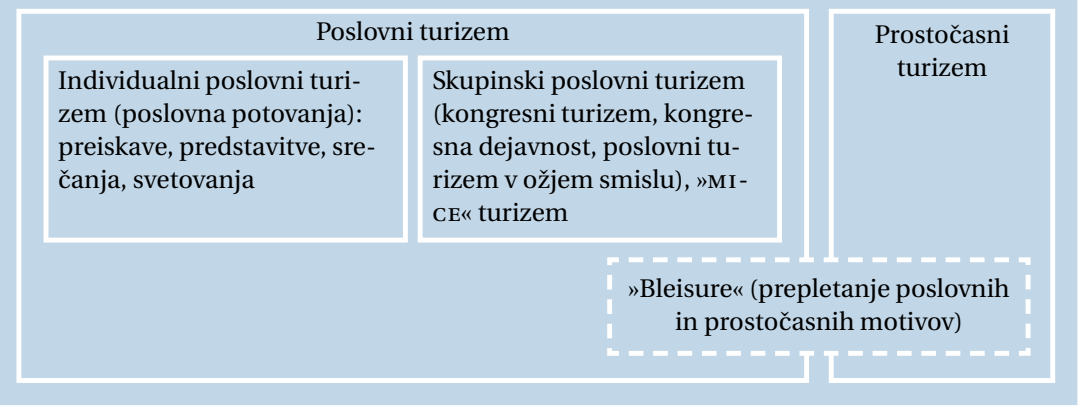

Slika 7.1 Koncept poslovnega turizma v odnosu do turizma (prirejeno po Sikošek, 2017)

v širši konceptualni okvir turizma zaradi razumevanja dveh oblik turizma, ki imata v kontekstu preživljanja časa posameznika za namen potovanja različna izhodišča.

Čeprav gre za različnost namena potovanja, pa se poslovni in prostočasni turizem nemalokrat tudi prekrivata, in sicer avtorji (Oppermann, 1996a; Rogers, 1998; Swarbrooke in Horner, 2001; Cassar idr., 2020) izpostavljajo predvsem vključevanje dejavnosti prostočasne turistične ponudbe v kongresno ponudbo, kar je izraziteje pri pripravi motivacijskih potovanj in programov za spodbujanje sodelovanja v skupini (t.i. programov team-building), vključevanju spremljevalcev udeležencev $\mathrm{v}$ poslovno potovanje in podaljševanju bivanja iz poslovnih razlogov v prostočasno bivanje. Slednje dobiva svoj izraz, »bleisure«, ki je skovanka pojmov »business « in »leisure« ali tudi »business « in "pleasure $($ Lee, 2020).

V raziskovanje in strokovna poročila kongresne industrije je vključena le skupinska oblika poslovnega turizma. Rogers (1998) to utemeljuje z dejstvom, da individualna poslovna potovanja, kljub temu da so številčnejša, niso podvržena vnaprejšnji izbiri destinacije ali srečanja samega, saj jih določajo službene naloge in jih zato imenuje "neodločilna«, medtem ko so pri skupinski obliki destinacije in prizorišča podvržena končni izbiri organizatorjev in udeležencev poslovnih srečanj ter so zato »odločilna«.

Za skupinski poslovni turizem se $\mathrm{v}$ slovenščini uporablja izraze "poslovni turizem«, »kongresni« ali »konferenčni turizem«, v tuji literaturi pa najdemo različna poimenovanja, kot so business tourism (Swarbrooke in Horner, 2001), convention tourism (Weber in Chon, 
2002), meeting tourism (Mohammadi in Mohamed, 2011), convention and meeting tourism (Oppermann, 1996b), congress tourism (Dragićević idr., 2009) ali kongresni turizam (Lucianović, 1980).

Definicijo kongresnega turizma je v Evropi leta 1970 podal AIEsT (The International Association of Scientific Experts in Tourism), ki ga definira kot »skupek pojavov in odnosov, ki izhajajo iz potovanja in bivanja oseb, ki se sestajajo večinoma zaradi izmenjave znanstvenih in strokovnih informacij in jim kraj srečanja ni stalno mesto bivanja ali zaposlitve« (Lucianović, 1980).

Pogosto se uporablja alternativni izraz »kongresna industrija«, v Sloveniji tudi »kongresna dejavnost«, saj naj bi imel kongresni turizem prav zaradi ekonomskih učinkov, ki jih ustvarja, in koristi, ki jih prinaša destinaciji, ter možnosti za izmenjavo idej, poslovnega mreženja in priložnosti za ustvarjanje napredka značaj industrije (Weber in Chon, 2002). V literaturi se srečujemo z različnimi poimenovanji, kot so: meetings industry ali conventions and meetings industry (Crouch in Louviere, 2004), conference industry (Rogers, 1998), convention industry (Jago in Deery, 2005), conference business (Opperman in Chon 1997) ali business events (Mair in Thompson, 2009).

Zaradi nedorečenosti izrazov se je na potrebo po statističnem spremljanju gibanja poslovnega turizma leta 2006 odzvala Svetovna turistična organizacija (World Tourism Organization), ki je kongresno industrijo opredelila kot meetings industry, kar v prostem prevodu pomeni industrija srečanj. Odločitev utemeljuje z dejstvom, da ta »industrija « vključuje organizacijo, promocijo in management poslovnih/kongresnih prireditev, kot so prodajne razstave, kongresi, konference in korporativna srečanja, ki vključujejo upravljanje ter zagotavljanje specializiranih prostorov in osebja, izraz srečanja pa z dejstvom, da je ključna sestavina katere koli poslovne prireditve srečanje ljudi, ki je organizirano s pomočjo strokovnega organizatorja (World Tourism Organization, 2006, str. 18-19).

Čeprav Svetovna turistična organizacija v omenjenem dokumentu priporoča promocijo izraza »industrija srečanj«, pa se vendarle uporablja tudi veliko drugih, med drugim tudi "poslovna srečanja « (angl. business meetings). Najpogosteje pa je v literaturi in stroki zaslediti akronim "MICE«, ki velja za krovni pojem poslovnega turizma, kot splošen izraz za vsa srečanja, kot so konference, kongresi, motivacijska potovanja in razstave, pa tudi kot sinonim za poslovni/kongresni turizem (Weber in Chon, 2002; Mair, 2013). 
Rogers (2008) se sprašuje, ali je takšna raznolikost v resnici posledica raznovrstnosti kongresnih prireditev ali bolj posledica raznoličnosti angleškega jezika, v katerem potekajo akademske in strokovne razprave. Podrobnejši pregled literature kaže, da gre le v manjšem obsegu za dejansko razliko med posameznimi vrstami prireditev, pogosto pa za različen jezikovni prostor. Na podobne pojmovne izzive posebej opozarja tudi A. Ladkin (2006), ki trdi, da je v raziskovanju kongresnega turizma velik izziv pravilno definiranje te oblike turizma in uporaba terminologije različnih vrst poslovnih srečanj oz. prireditev.

Čeprav gre za neenotno rabo različnih izrazov, je pomembno, da jih zaradi lažjega razumevanja natančneje pojasnimo tudi v slovenskem jeziku. Pri tem se opiramo na opredelitve tujih avtorjev in strokovno rabo, ki je običajna v slovenskih strokovnih virih (Zidanski, 2005; Turizem Ljubljana, 2011):

- poslovni turizem velja za najširši pojem, ki zajema individualna in skupinska poslovna srečanja;

- kongresni turizem je pojem, ki zajema organizacijo različnih kongresnih aktivnosti v smislu potovanja več oseb izven kraja njihovega stalnega prebivanja $\mathrm{z}$ namenom medsebojnega srečanja na poslovni (kongresni) prireditvi zaradi izmenjave znanja, informacij, ki v času potovanja koristijo kongresno, turistično in splošno infrastrukturo ter storitve;

- kongresna dejavnost je pojem, povezan z organizacijo različnih poslovnih prireditev, kot so kongresi, konference, poslovna srečanja, motivacijska/nagradna potovanja, razstave in sejmi; pomeni organizacijske dejavnosti ponudnikov in naročnikov poslovnih srečanj ter ustvarjanje ugodnega okolja za izmenjavo znanja, poslovnih povezav in dogovorov, ki prispevajo k rasti ekonomskega in družbenega okolja, pri čemer se ta pojem pomensko prekriva s pojmoma "kongresna industrija» ali »industrija srečanj « ter »kongresni turizem«;

- poslovna srečanja ali poslovne prireditve so splošno poimenovanje za vse oblike srečanj oz. potovanj večjih skupin posameznikov iz poslovnih razlogov, kot so konference, kongresi, znanstvena srečanja, motivacijska ali nagradna potovanja, poslovni sestanki, razstave in sejmi;

- kongresna/konferenčna prireditev je poimenovanje za poslovna 
srečanja, kot so kongresi, konference, konvencije, znanstveni sestanki in znanstvena srečanja.

Zaključujemo z ugotovitvijo, da poslovni turizem v njegovem najšišem pomenu razumemo kot potovanje oseb iz poslovnih razlogov izven kraja njihovega stalnega prebivanja z namenom izmenjave znanj in informacij ter ustvarjanja novih poslovnih priložnosti na poslovnem srečanju (prireditvi); pri čemer štejemo med kongresni turizem tiste njegove oblike, ki se jih udeleži več ljudi naenkrat, njihova organizacija pa zahteva koriščenje specializiranih kongresnih storitev ter splošne in turistične infrastrukture in storitev.

\section{Vrste in značilnosti poslovnih prireditev}

Poslovni turizem pomeni potovanje posameznikov iz poslovnih razlogov, temeljni motiv potovanja pa je udeležba na poslovni prireditvi, ki predstavlja njegov osnovni produkt. Že pri opredeljevanju koncepta poslovnega turizma smo ugotovili, da pri tem obstajata precejšnja neenotnost in nedorečenost. Podobno je pri opredelitvi različnih vrst poslovnih prireditev oz. poslovnih srečanj. V literaturi (Weber in Chon, 2002; Mair, 2013; Getz in Page, 2016) in praksi se je še najbolj uveljavila raba akronima MICE kot krovnega pojma, ki zaobjema štiri osnovne tipe poslovnih prireditev in je pogosto sinonim za poslovni ali kongresni turizem ali kongresno dejavnost, še bolj pa se v praksi navezuje na izraz industrija srečanj. Tipologijo poslovnih prireditev, ki spadajo pod akronim MICE, predstavljamo na sliki 7.2.

V literaturi je sicer opaziti dvome, da bi motivacijska potovanja (angl. incentives) uvrščali v zgornjo tipologijo poslovnih prireditev (Mair, 2013; Getz in Page, 2016), saj naj bi bila takšna potovanja bolj orodje nagrajevanja managerjev kot pa poslovno srečanje (Mair, 2013). Zato se pojavljajo tudi akronimi MEcE (Meetings, Events, Conventions, Exhibitions), MCE (Meetings, Conventions, Exhibitions) (Weber in Chon, 2002) ali MEEc (Meetings, Expositions, Events and Conventions) (Fenich, 1995; DiPietro idr., 2008), MCE (Meeting, Convention and Exhibition) (Huo, 2014) ali CемI (Conventions, Exhibitions, Meetings, Incentives) (Weber in Chon, 2002), ki pa se ga redkeje uporablja. V literaturi so definicije pogosto povzete po definicijah vodilnih strokovnih organizacij s področja kongresne dejavnosti, kot so Events Industry Council (EIC), International Congress in Convention Association (ICCA), The International Association of Pro- 

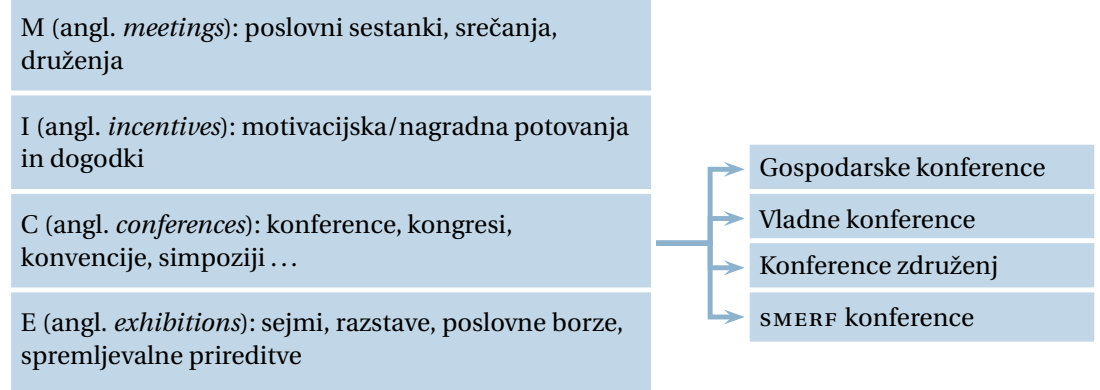

Slika 7.2 MICE tipologija poslovnih srečanj

fessional Congress Organisers (IAPCO) in Kongresni urad Slovenije (KUs). Svetovna turistična organizacija (World Tourism Organization, 2006) opozarja, da ne glede na vrsto poslovnega srečanja velja, da mora ta potekati izven sedeža organizacije $v$ najetih prostorih, na kongresnem prizorišču, če ga želimo opredeliti kot takšno. V literaturi (Seekings, 1992; Rogers, 1998; Ladkin, 2002; Weber in Chon, 2002; World Tourism Organization, 2006; Mair, 2013) se poimenovanja vse od zgodnjih začetkov v grobem ločujejo glede na namen, lokacijo srečanja in število udeležencev.

Prva skupina poslovnih prireditev so poslovna srečanja (angl. meetings), kjer prihaja do največjih razhajanj v mnenjih, kaj naj bi pomenila. Načeloma gre za dvoje: za splošen pojem, ki obsega vsa srečanja ljudi iz poslovnih razlogov v kontekstu skupinskega poslovnega turizma in se nanaša na vse vrste poslovnih srečanj. Lahko pa pomeni tudi samostojno poslovno srečanje, katerega primarni namen je sodelovanje v diskusiji, udeležba na izobraževalnih in/ali poslovnih sestankih in naj bi pomenilo "srečanje najmanj 10 posameznikov za najmanj štiri ure v najetih prostorih" (Mair, 2013; World Tourism Organization, 2006; Mair, 2013). Kot poudarja J. Mair (2013), so v nekaterih primerih poslovne prireditve mišljene kot velike prireditve, včasih kot manjša srečanja posameznikov, pogosto se različne vrste srečanj prekrivajo z drugimi (na primer kongres in razstava). Med vsemi opredelitvami je prav opredelitev izraza poslovno srečanje najrazličnejša, vendar pa se na splošno najpogosteje uporablja kot sinonim za poslovne sestanke ali velika srečanja mednarodnih združenj.

Motivacijska ali nagradna potovanja (angl. incentives, incentive travel, incentive trip) mednarodna strokovna organizacija na 
področju motivacijskih potovanj site (Society for Incentive Travel Excellence) opredeljuje kot koncept nedenarnega nagrajevanja zaposlenih z udeležbo na potovanju, ki so zaradi izjemne potovalne izkušnje motivirani v podjetju doseči več od običajnih ciljev (Mair, 2013). Vsebinsko so potovanja "incentive« in dogodki srečanja sodelavcev v različnih programih doživetij in programih "teambuilding «, kot je na primer kulinarično doživetje, adrenalinsko doživetje ipd. (Slovenian Convention Bureau, 2014). Čeprav sta motivacijsko potovanje in dogodek orodji za nagrajevanje zaposlenih, ju uvrščamo med poslovna srečanja, saj J. Mair (2013) opozarja, da gre vendarle za del poslovne strategije podjetja, s čimer je opredeljen poslovni namen potovanja.

Sejmi in razstave (angl. exhibitions, trade shows, expositions, trade fairs) so poseben segment poslovnih srečanj, ki je namenjen razstavljanju, prikazovanju in preizkušanju izdelkov ter storitev ter predstavlja prostor in priložnost za poslovne dogovore ter druženja. Rittichainuwat in J. Mair (2012) sicer opozarjata, da je treba ločiti med različnimi vrstami sejmov in razstav, saj v segment "MICE« spadajo samo tista, ki so namenjena poslovni javnosti in ne končnemu potrošniku (angl. consumer fairs).

Največ posebnosti in dilem je opaziti pri tipu poslovnega srečanja kongres, konferenca oz. konvencija. $\mathrm{V}$ bistvu gre poglavitno razliko iskati med pojmoma konferenca in kongres ter med pojmoma konferenca in konvencija. Ugotovitvam avtorjev je namreč skupno to, da je izraz »konvencija " pogostejši v Ameriki, Avstraliji in Aziji, medtem ko se v Evropi pogosteje uporablja izraz »kongres« (Lucianović, 1980; Rogers, 1998; Mair, 2013).

Večina vseh opredelitev za konferenco enotno povzema, da gre za poslovno srečanje $\mathrm{v}$ manjšem obsegu glede na število udeležencev in stopnjo zahtevnosti programa (vsebine), srečanje je organizirano predvsem zaradi izmenjave mnenj, razprave o točno določeni temi neke ožje, specifične skupine posameznikov (Rogers, 1998; Ladkin, 2002; Zidanski, 2005). Pomembni značilnosti sta tudi obdobje trajanja, ki je običajno krajše kot pri kongresih, ter frekvenca ali periodičnost ponavljanja. Za konference namreč velja, da običajno ne poznajo rednega ponavljanja v določenem časovnem obdobju (World Tourism Organization, 2006; Turizem Ljubljana, 2011).

Kongres je srečanje, ki je po svojem obsegu običajno večje kot konferenca, tako glede števila udeležencev kot zahtevnosti programa. 
Vsebina je zastavljena zelo široko, program kongresa je zato običajno razdeljen na več simultanih sekcij in lahko traja dalj časa (Rogers, 1998; World Tourism Organization, 2006; Turizem Ljubljana, 2011). Pomembna lastnost je njegova frekvenca oz. ponavljanje, kar pomeni, da se odvija v rednih časovnih presledkih (letni, večletni), pri čemer so kongresi na nacionalni ravni običajno organizirani na letni osnovi, mednarodni pa na večletni.

Najmanj dorečen je izraz konvencija (angl. convention), ki pomeni srečanje velikega števila oseb z določeno dolžino trajanja, vendar brez periodičnega ponavljanja (World Tourism Organization, 2006). Tradicionalno se pogosteje uporablja v ameriških in azijskih državah (Lucianović, 1980; Rogers, 1998), medtem ko je v Evropi za to vrsto srečanja pogosteje uporabljen izraz kongres. Sicer ta izraz pomeni tudi zborovanje ali shod oz. tudi podpisovanje sporazumov med državami ali podjetji, čemur se približujejo tudi nekatere definicije v kongresni praksi (Seekings, 1992; World Tourism Organization, 2006). Ko govorimo o konferenci, kongresu in konvenciji, je treba omeniti še njihov mednarodni značaj. Za mednarodno štejemo tisto, ki ustreza opredelitvi strokovnega združenja The International Congress and Convention Association (ICCA) in Union of International Associations (UIA). Po definiciji ICCA je mednarodno srečanje tisto, ki poteka redno (tradicionalno), kroži med najmanj tremi državami in ima najmanj 50 udeležencev. UıA za mednarodna srečanja šteje tista, kjer najmanj $40 \%$ udeležencev prihaja iz petih različnih držav, ki trajajo najmanj 2 dni in štejejo najmanj 250 udeležencev (International Congress and Convention Association, 2018). Pri opredelitvi konference, kongresa in konvencije je treba poleg mednarodnosti izpostaviti še njihovo delitev glede na to, iz katerega poslovnega sektorja izhaja naročnik (organizator) srečanja, kar predstavljamo $\mathrm{v}$ nadaljevanju.

V zvezi s tipologijo poslovnih srečanj je nujno poudariti, da mednje ne uvrščamo družabnih srečanj prostočasne narave (npr. porok), stalnih, formalnih izobraževanj, prostočasnih aktivnosti (npr. koncertov), političnih shodov in kampanj, prodajnih razstav in srečanj končnih potrošnikov (World Tourism Organization, 2006).

\section{Zgodovina razvoja poslovnega turizma}

Potovanja iz poslovnih razlogov segajo daleč v zgodovino človeka. K. Weber in Chon (2002, str. xix) navajata, da je človekova potreba po 
srečevanju in izmenjavi idej, kar je osnova konferenc in poslovnih srečanj, stara toliko kot človeštvo. Prvotna srečevanja ljudi iz poslovnih razlogov so bila namenjena ne le izmenjavi idej in znanja, temveč tudi trgovanju, in se v svojem bistvu od srečanj moderne dobe pravzaprav ne razlikujejo prav veliko.

Prvo obdobje predstavlja obdobje antike. J. Spiller (2002) izpostavlja dejstvo, da ostanki iz antične dobe pričajo o bogati človekovi dejavnosti na področju izmenjave znanja in proizvodov v Perziji, stari Grčiji in starem Rimu. Prav slednjemu avtorji (Spiller, 2002; Rogers, 1998; Shone, 1998) pripisujejo začetke terminologije, ki jo še danes uporabljamo. Temeljni izraz "konferenca « izhaja iz latinskega conferentia oz. conferre, ki pomeni "združiti, zbrati«, ali izraz congressus, ki pomeni "sestanek, srečanje, shod", ali izraz auditorium kot "prostor za poslušalce« (Spiller, 2002, 3; Fran, 2019). Drugo obdobje je čas v srednjem veku, ko gre za srečevanja verskih dostojanstvenikov, trgovcev in vojaških predstavnikov zaradi političnih ali ekonomskih dogovorov. Pomemben mejnik v razvoju poslovnih potovanj predstavljajo potovanja po Svilni poti, ko so se ob poti zaradi dolžine potovanj razvila posamezna postajališča in namestitve ter kasneje večja mesta (Swarbrooke in Horner, 2001; Rogers, 1998).

Pomemben mejnik predstavlja industrializacija v 18. in 19. stoletju, ki je botrovala razvoju prevoznih sredstev in potrebi po srečevanjih iz poslovnih razlogov (Swarbrooke in Horner, 2001; Ford, 2008). Shone (1998) navaja, da so v Britaniji poslovna srečanja potekala v večjih gostiščih ob prometnicah, kasneje v bolje opremljenih hotelih in $\mathrm{v}$ letoviščih pa tudi univerzitetnih prostorih. V Evropi velja za začetnika vladnih srečanj kongres Sv. alianse na Dunaju od septembra 1814 do junija 1815 in leta 1821 v Ljubljani, za katerega Rogers (2008) trdi, da velja za enega največjih predhodnikov kongresov moderne dobe, saj je razvil lastno organizacijsko strukturo, primerljivo z današnjimi večjimi mednarodnimi kongresi, predsedoval mu je predsednik, imel je svoj sekretariat in delovne odbore ter začel s tradicijo prirejanja rednih srečanj. Industrializacija je ob prelomu v 20. stoletje zlasti v Združenih državah Amerike poudarila potrebo po organizaciji poslovnih srečanj, kar je vodilo do ustanovitve prvega kongresnega urada leta 1896 v Detroitu (Ford, 2008). Zaradi 2. svetovne vojne je razvoj kongresne dejavnosti v prvi polovici 20. stoletja predvsem $\mathrm{v}$ Evropi nekoliko zastal (Swarbrooke in Horner, 2001).

Čas po letu 1950 velja za obdobje vzpona moderne kongresne de- 
javnosti, ko je bila potreba po poslovnih potovanjih in srečanjih vedno večja, in sicer tako v zahodni Evropi kot Združenih državah Amerike. Kasneje, v 7o-ih letih prejšnjega stoletja, se ta trend prenese še v Azijo, Avstralijo in Afriko. Za to obdobje sta poleg naraščanja števila poslovnih srečanj značilna tudi razvoj kongresne infrastrukture in kongresnih ponudnikov oz. storitev ter pojav sistematičnega spremljanja razvoja kongresne dejavnosti (Spiller, 2002; Rogers, 2008).

Poslovna srečanja so stara toliko kot človeštvo, spreminjala so se v odvisnosti od gospodarskega in tehnološkega razvoja, ves čas pa izkazujejo veliko človekovo potrebo po medsebojni izmenjavi idej, znanja in izkušenj ter težnjo, da srečanje prispeva nove dogovore, znanje in izhodišča za nadaljnji razvoj, kar štejemo kot ključen prispevek poslovnih srečanj in poslovnih potovanj. Ob tem se sprašujemo, ali ni morda prav zaradi svoje specifičnosti poslovni turizem najstarejša oblika turizma, saj so ljudje najprej začeli potovati zaradi nujnosti menjave dobrin in znanja, medtem ko se kategorija prostega časa, ki je nujna sestavina prostočasnega turizma, pojavi kasneje.

\section{Ključni deležnilki v poslovnem turizmu}

Osnovni produkt v poslovnem turizmu je poslovno srečanje ne glede na vrsto. Oblikujejo ga naročniki srečanj in ponudniki kongresnih storitev, nanj pa s svojimi pričakovanji vplivajo tudi kongresni udeleženci, ki predstavljajo ključne deležnike v poslovnem turizmu (Sikošek, 2017). Prikazani so na v preglednici 7.1.

Naročniki/organizatorji srečanj so v poslovnem turizmu običajno organizacije in podjetja, ki jih obravnavamo tudi kot pobudnike za organizacijo srečanj. Davidson in Rogers (2006) navajata, da so organizacije ustvarjalci povpraševanja po konferencah, ki pobudo sprožijo zaradi potrebe po srečanju svojih članov ali zaposlenih na določenem mestu in v določenem času. Naročnike oz. pobudnike srečanj v osnovi delimo v štiri skupine (Rogers, 1998; Swarbrooke in Horner, 2001; Davidson in Rogers, 2006; Mair, 2013), razlika med njimi nastaja v poslovni usmerjenosti (profitno/neprofitno). Običajno sta v praksi najpogostejši dve skupini. Prvo običajno sestavljajo profitno usmerjena podjetja in korporacije, ki tvorijo segment korporativnih srečanj. Drugo skupino predstavljajo profesionalna združenja ali zveze združenj, ki združujejo posameznike podobnih profesionalnih usmeritev in tvorijo srečanja združenj. V Sloveniji za združenje upo- 
Preglednica 7.1 Ključni deležniki v poslovnem turizmu

\begin{tabular}{ll}
\hline $\begin{array}{l}\text { Naročniki/organizatorji } \\
\text { srečanj }\end{array}$ & $\begin{array}{l}\text { Podjetja in korporacije } \\
\text { Strokovna združenja in zveze } \\
\text { Javne, vladne/medvladne ustanove } \\
\text { "SMERF« organizacije }\end{array}$ \\
\hline Ponudniki storitev & $\begin{array}{l}\text { Specializirane kongresne storitve na destinaciji: PCO, } \\
\text { kongresna prizorišča, kongresne nastanitve, DMC, } \\
\text { posredniki (KU, PCO), druge kongresne storitve }\end{array}$ \\
\cline { 2 - 2 } & $\begin{array}{l}\text { Druge storitve na destinaciji: turistične storitve, } \\
\text { splošne storitve }\end{array}$ \\
\hline Udeleženci srečanj & $\begin{array}{l}\text { Aktivni udeleženci in vabljeni govorci } \\
\text { Pasivni udeleženci } \\
\text { Spremljevalci }\end{array}$ \\
\hline
\end{tabular}

rabljamo tudi izraza »društva« ali »zveze«. Tretja skupina so organizacije javnega in vladnega sektorja, kamor uvrščamo javne ustanove ter vladne in politične institucije, ki tvorijo segment vladnih srečanj. Posebno (četrto) skupino predstavljajo izobraževalne, verske, socialne in vojaške ustanove ali "SMERF« (angl. social, military, educational, religious, fraternal institutions) (Davidson in Rogers, 2006; Rogers, 2008). Srečanja javnih ustanov in organizacij SMERF zaradi njihovih skupnih lastnosti uvrščamo v skupino srečanj združenj.

Udeleženca poslovnega srečanja zaradi poslovne narave potovanja imenujemo tudi poslovni turist (Rogers, 1998), razumemo pa ga tudi kot končnega potrošnika poslovnega srečanja (Mair, 2013; Cassar idr., 2020) oz. potrošnika vseh storitev, ki so vključene v izvedbo srečanja, saj poravnajo kotizacijo za udeležbo na konferenci in trošijo za druge storitve na gostiteljski destinaciji, kar je temeljnega pomena za obstoj poslovnega/kongresnega turizma. Oppermann in Chon (1997) opozarjata, da je med udeleženci glede na vrsto srečanja pomembna razlika, saj udeleženec korporativnega srečanja za razliko od udeleženca srečanja združenja nima možnosti izbire srečanja in destinacije, saj mu jo vnaprej določi podjetje. Med udeleženci srečanj združenj ločujemo med udeleženci $v$ širšem in ožjem smislu. V širšem smislu so to udeleženci, ki kongresno destinacijo obiščejo zaradi udeležbe na kongresu skupaj s spremljevalci, ki pogosto pomembno vplivajo na udeležbo. Takšen tip udeleženca je značilnejši za srečanja združenj. V ožjem smislu pa gre tiste, ki aktivno prispevajo k vsebini konference in so člani združenja ali podjetja (angl. participating members) oz. nečlani združenja (angl. participating non- 
members) in pasivni udeleženci (angl. non-participating members). Udeleženci, ki jih ne spremljajo spremljevalci, so značilni za korporativna srečanja.

Ponudniki v poslovnem turizmu so specializirani za izvajanje kongresnih storitev na gostiteljski destinaciji in se zaradi organizacije srečanja povezujejo tudi $\mathrm{z}$ drugimi ponudniki storitev (Swarbrooke in Horner, 2001; Rogers, 2008). Vezni člen med ponudniki in naročniki predstavljajo posredniki (angl. intermediaries) (Davidson in Rogers, 2006). Specializirani ponudniki v kongresnem turizmu, ki delujejo na kongresni destinaciji, so ponudniki kongresnih prizorišč, profesionalni kongresni organizator (angl. professional congress organizer), destinacijska kongresna agencija (angl. destination management company), ponudniki (kongresnih) nastanitev, ponudniki drugih kongresnih storitev (specializirane storitve keteringa, agencije za organizacijo dogodkov, iskanje prizorišč, ponudniki kongresnotehničnih storitev) in posredniki, med katerimi je najznačilnejši ponudnik kongresni urad.

Kongresno prizorišče (angl. venue, site) je prostor, na katerem bo potekalo poslovno srečanje; lahko je zunanje ali notranje (Shone, 1998; Swarbrooke in Horner, 2001; Davidson in Rogers, 2006), mora pa biti prostorsko omejeno oz. določeno. Poznamo jih več vrst, med seboj se razlikujejo glede na velikost, namembnost in opremljenost (Swarbrooke in Horner, 2001; Davidson in Rogers, 2006; Getz in Page, 2016) oz. receptivno zmogljivost prizorišča (Sikošek, 2017). V strukturi ponudbe prizorišč najdemo več različnih, predstavljamo jih v preglednici 7.2. Po poročilih strokovnih organizacij (World Tourism Organization, 2006; International Congress and Convention Association, 2018) je skoraj polovica vseh poslovnih srečanj organiziranih v hotelih, vendar pa je v zadnjih letih pri organizaciji prizorišč v ospredju njihova fleksibilnost pri postavitvi in inovativni opremljenosti, ki naj čim bolj poudari temo srečanja in daje udeležencem priložnost za mreženje ter izmenjavo znanja in idej (Cassar idr., 2020).

Med ponudniki kongresnih storitev bomo kot najznačilnejše izpostavili še tri. Prvi med njimi je profesionalni kongresni organizator (angl. professional congress/conference organizer), označujemo ga z akronimom pco. Deluje kot posrednik med naročnikom in kongresno destinacijo, v praksi pa je pogosto imenovan kar tehnični organizatorj kongresa, saj od naročnika prevzame celotno organizacijo in izvedbo kongresa, naročnik tako poskrbi le za njegovo vse- 
bino. PCo za naročnika opravi iskanje prizorišča, skrbi za namestitev udeležencev, trženje kongresa, stike z mediji, upravljanje s človeškimi viri, organizacijo potovalnih aranžmajev za udeležence, organizacijo spremljevalne razstave, urejanje avdiovizualnih storitev, organizacijo glavnega programa, organizacijo spremljevalnega programa konference, izvedbo procesa sprejemanja povzetkov in publiciranja konferenčnih publikacij, organizacijo konferenčnih sekcij, varnost in varovanje, upravljanje s finančnimi sredstvi in oblikovanje proračuna ter pripravo pogodb (Davidson in Rogers, 2006; Rogers, 2008). V Sloveniji imamo le nekaj takšnih ponudnikov, med najbolj uveljavljenimi so Cankarjev dom, Albatros Bled in Toleranca Marketing.

Drugi specializiran ponudnik je destinacijska agencija (angl. destination management company) ali s kratico DMc. To je posrednik, ki zastopa interese naročnikov oz. organizatorjev. Deluje kot specializirana turistična agencija za kongresno dejavnost, specializirana za opravljanje storitev, ki so povezane s poznavanjem gostiteljske destinacije. V največjem obsegu se ukvarja z izvajanjem logističnih storitev, organizacijo spremljevalnega programa poslovnega srečanja (konferenčni izleti pred konferenco ali po njej, kreativne rešitve za posebne dogodke), nastanitev ter motivacijskih potovanj in programov (Davidson in Rogers, 2006; Rogers, 2008).

Najznačilnejši posrednik, ki predstavlja interese ponudnikov kongresnih storitev na destinaciji, je kongresni urad, ki deluje kot destinacijska trženjska organizacija (angl. destination marketing organization). V stroki je bolj prepoznaven pod akronimom cvB (angl. Convention and Visitors Bureau). Njegove primarne naloge so izvajanje trženjskih dejavnosti kongresne destinacije, predvsem njena promocija potencialnim organizatorjem oz. naročnikom, povezovanje ponudnikov kongresnih storitev na destinaciji ter podpora pri trženjskih dejavnostih svojih članov. Običajno je kongresni urad organiziran kot neprofitna organizacija, ki deluje v javno-zasebnem partnerstvu po načelu članstva. Prvi kongresni urad v Evropi je nastal v Nemčiji leta 1973, leto pozneje pa še na Finskem (Davidson in Rogers, 2006). V Sloveniji na nacionalni ravni deluje Zavod - Kongresnoturistični urad Slovenije, krajše Kongresni urad Slovenije, ki je bil ustanovljen leta 2003. Kot samostojni lokalni kongresni urad deluje po eden na Bledu in v Ljubljani, drugače pa naloge trženja in promocije kongresnih storitev in destinacije opravljajo lokalne destinacijske 
Preglednica 7.2 Struktura ponudbe kongresnih prizorišč

\begin{tabular}{|c|c|c|c|}
\hline \multirow[t]{2}{*}{$\begin{array}{l}\text { Hoteli: kongresni } \\
\text { hoteli in drugi ho- } \\
\text { teli z dvoranami } \\
\text { (angl. congress ho- } \\
\text { tels) }\end{array}$} & $\begin{array}{l}\text { Kongresni } \\
\text { hotel (stan- } \\
\text { dard F) }\end{array}$ & $\begin{array}{l}\text { Hotelska nastanitev v ka- } \\
\text { tegoriji min. } 4^{*} \text {; ponudba } \\
\text { kongresnih dvoran s širo- } \\
\text { kim naborom tehničnih } \\
\text { storitev; gostinske stori- } \\
\text { tve; število hotelskih sob } \\
\text { v razmerju s številom se- } \\
\text { dežev v največji dvorani; } \\
\text { lasten kongresni oddelek } \\
\text { ali prodajna služba z ose- } \\
\text { bjem, ki ima izkušnje na } \\
\text { kongresnem področju. }\end{array}$ & $\begin{array}{l}\text { Grand Hotel Uni- } \\
\text { on, Four Points by } \\
\text { Sheraton Ljublja- } \\
\text { na Mons, Austria } \\
\text { Trend Hotel Ljub- } \\
\text { ljana, Grand hotel } \\
\text { Bernardin, Hotel } \\
\text { Slovenija. }\end{array}$ \\
\hline & $\begin{array}{l}\text { Hotel s kon- } \\
\text { ferenčnimi } \\
\text { zmogljivost- } \\
\text { mi (stan- } \\
\text { dard G) }\end{array}$ & $\begin{array}{l}\text { Hotelska nastanitev v ka- } \\
\text { tegoriji min. } 3^{*} \text {; vsaj ena } \\
\text { plenarna dvorana, doda- } \\
\text { tno vsaj ena dvorana za } \\
\text { vzporedna srečanja; pred- } \\
\text { prostor za pogostitev, re- } \\
\text { gistracijo udeležencev in } \\
\text { organizacijo manjše raz- } \\
\text { stave; restavracija ne more } \\
\text { biti konferenčni prostor. }\end{array}$ & $\begin{array}{l}\text { Best Western Pre- } \\
\text { mier Hotel Slon, } \\
\text { Hotel Cubo, Ri- } \\
\text { kli Balance Hotel, } \\
\text { Grand Hotel Topli- } \\
\text { ce, Hotel Marko ... }\end{array}$ \\
\hline $\begin{array}{l}\text { Kongresni in raz- } \\
\text { staviščni centri } \\
\text { (angl. purpose- } \\
\text { built centres) }\end{array}$ & $\begin{array}{l}\text { Kongresni in } \\
\text { razstaviščni } \\
\text { center (stan- } \\
\text { dard E) }\end{array}$ & $\begin{array}{l}\text { Največji obseg kongresnih } \\
\text { zmogljivosti po številu se- } \\
\text { dežev in številu dvoran; } \\
\text { tehnična podpora za iz- } \\
\text { vedbo; nima nastanitve- } \\
\text { nih in gostinskih zmoglji- } \\
\text { vosti. }\end{array}$ & $\begin{array}{l}\text { Cankarjev dom, } \\
\text { Gospodarsko raz- } \\
\text { stavišče. }\end{array}$ \\
\hline
\end{tabular}

Nadaljevanje na naslednji strani

organizacije (zavodi za turizem, turistične organizacije ali združenja).

Druge specializirane kongresne storitve so vse tiste, ki so neposredno vključene pri organizaciji poslovnega srečanja, kot npr. organizacija ponudbe hrane in pijače (ketering), tehnične storitve, avdiovizualnih storitev, aranžerskih in cvetličarskih storitev, storitev tolmačenja in prevajanja, vodniških storitev, zavarovalnih storitev in drugih (Shone, 1998; Swarbrooke in Horner, 2001).

\section{Obseg kongresnega turizma v svetu}

Obseg kongresnega turizma lahko ocenimo na podlagi zbranih podatkov o številu poslovnih srečanj, številu udeležencev, trajanju kon- 
Preglednica 7.2 Nadaljevanje s prejšnje strani

\begin{tabular}{|c|c|c|c|}
\hline $\begin{array}{l}\text { Univerzitetni/fa- } \\
\text { kultetni prostori } \\
\text { (angl. college, uni- } \\
\text { versity) }\end{array}$ & - & $\begin{array}{l}\text { Prostori, primerni za iz- } \\
\text { vedbo kongresov zaradi } \\
\text { arhitekturne urejenosti } \\
\text { (predavalnice) in razisko- } \\
\text { valne usmerjenosti. }\end{array}$ & $\begin{array}{l}\text { Fakulteta za turi- } \\
\text { stične študije, Fa- } \\
\text { kulteta za družbe- } \\
\text { ne vede, Pravna fa- } \\
\text { kulteta... }\end{array}$ \\
\hline $\begin{array}{l}\text { Javne zgrad- } \\
\text { be/prizorišča (an- } \\
\text { gl. civic venues) }\end{array}$ & - & - & Občinske dvorane. \\
\hline $\begin{array}{l}\text { Posebna, neo- } \\
\text { bičajna prizori- } \\
\text { šča (angl. speci- } \\
\text { al/unusual venues) }\end{array}$ & $\begin{array}{l}\text { Posebna } \\
\text { prizorišča } \\
\text { (standard I) }\end{array}$ & $\begin{array}{l}\text { Posebna zaradi svoje kul- } \\
\text { turne, zgodovinske, arhi- } \\
\text { tekturne ali tehnične vre- } \\
\text { dnosti; min. infrastruktur- } \\
\text { na opremljenost za izved- } \\
\text { bo srečanj; nima nastani- } \\
\text { tev. }\end{array}$ & $\begin{array}{l}\text { Ljubljanski grad, } \\
\text { Dvorana Stoži- } \\
\text { ce, skladišče soli } \\
\text { Monfort, Filmski } \\
\text { studio Viba film, } \\
\text { ladje, rezidence.... }\end{array}$ \\
\hline $\begin{array}{l}\text { Prostori večjih } \\
\text { podjetij }\end{array}$ & - & $\begin{array}{l}\text { Poslovne stavbe in prosto- } \\
\text { ri, namenjeni za izvedbo } \\
\text { poslovnih srečanj. }\end{array}$ & $\begin{array}{l}\text { Domus Medica, } \\
\text { Kristalna palača, } \\
\text { Gospodarska zbor- } \\
\text { nica ... }\end{array}$ \\
\hline Druga prizorišča & - & $\begin{array}{l}\text { Kompleksna kongresna } \\
\text { prizorišča (ponujajo vse } \\
\text { storitve destinacije); pri- } \\
\text { zorišča, ki prvotno niso } \\
\text { namenjena srečanjem. }\end{array}$ & $\begin{array}{l}\text { Tematski park, ži- } \\
\text { valski vrt. }\end{array}$ \\
\hline
\end{tabular}

Opombe Prirejeno po Swarbrooke in Horner (2001), Davidson in Rogers (2006), Mair (2013), Getz in Page (2016), Sikošek (2017).

gresa ter drugih podatkih, vendar A. Ladkin (2002) opozarja, da je razpoložljivost konsistentnih podatkov relativno nizka. Težavnost zbiranja podatkov izhaja iz razdrobljenosti dejavnosti ter relativne nepripravljenosti deležnikov za zbiranje in sporočanje podatkov, kar potrjujejo naše izkušnje iz predhodne raziskave (Sikošek idr., 2014). Mednarodni strokovni združenji ICcA in UIA že slabih šest desetletij kontinuirano in po enaki metodologiji zbirata podatke o srečanjih združenj na mednarodni ravni za vse svetovne regije. Čeprav je potrebno njune podatke interpretirati s previdnostjo, ker veljajo samo za destinacije (države in mesta), ki so njuni člani, in samo za mednarodna srečanja združenj, ti kljub tej omejitvi omogočajo vpogled $\mathrm{v}$ gibanje in obseg poslovnih srečanj v svetu.

Za prikaz obsega poslovnih srečanj smo izbrali podatke združenja ICCA za obdobje od leta 1963 do leta 2017. Prikazali bomo gibanje 


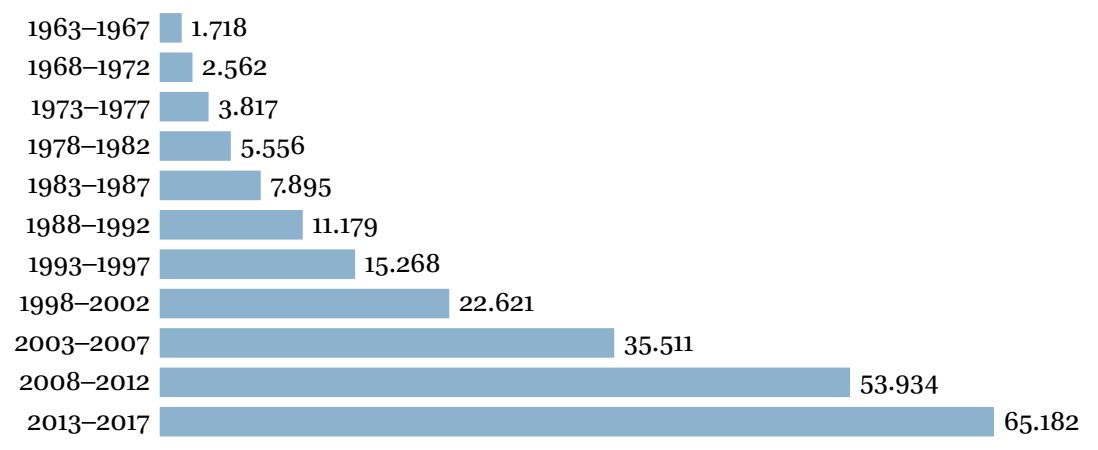

Slika 7.3 Gibanje števila srečanj v obdobju od leta 1963 do 2017 (prirejeno po International Congress and Convention Association, 2018, str. 22)

števila srečanj v svetu, povprečno število udeležencev na srečanje in število srečanj po posameznih svetovnih regijah.

Na sliki 7.3 vidimo, da se je število mednarodnih srečanj združenj od 6o-ih let prejšnjega stoletja povečevalo, najhitreje pa od 9o-ih let dalje. Hitro stopnjo rasti lahko pripišemo večji dostopnosti do prometnih sredstev in razvoju infrastrukture, gospodarstva in tehnologije, ki je povečala tudi potrebo po izmenjavi znanja, idej in poslovnih priložnosti, kar ugotavljata tudi Jago in M. Deery (2010).

Skladno z rastjo števila srečanj je naraščalo tudi absolutno število vseh udeležencev srečanj, kar je pričakovano, vendar pa je povprečno število udeležencev na posamično srečanje v obdobju od leta 1963 do 2017 padalo, kar prikazujemo na sliki 7.4. To pomeni, da je kongresnih srečanj vedno več, vendar z manj številčno udeležbo, kar nakazuje pojav vse večje konkurenčnosti kongresnega trga. Hkrati s tem se spreminja velikost srečanj: vse manj pogosta so postala srečanja $\mathrm{z}$ več tisoč udeleženci na srečanje, kar je bilo značilno za 60. in 7o. leta, v zadnjih dveh desetletjih pa so najpogostejša tista $\mathrm{z}$ do 150 udeleženci na srečanje (International Congress and Convention Association, 2018, str. 30). Vzporedno z zniževanjem števila udeležencev na srečanje se skrajšuje tudi povprečno trajanje srečanj; ta so v 6o-ih trajala povprečno 5,6 dneva, v zadnjih petih letih pa trajajo povprečno 3,6 dneva (International Congress and Convention Association, 2018, str. 41).

V preglednici 7.3 vidimo, da v svetovnem merilu med kongresnimi regijami v celotnem opazovanem obdobju prevladuje Evropa, saj gosti več kot polovico vseh srečanj na svetu. Do preloma tisočletja 


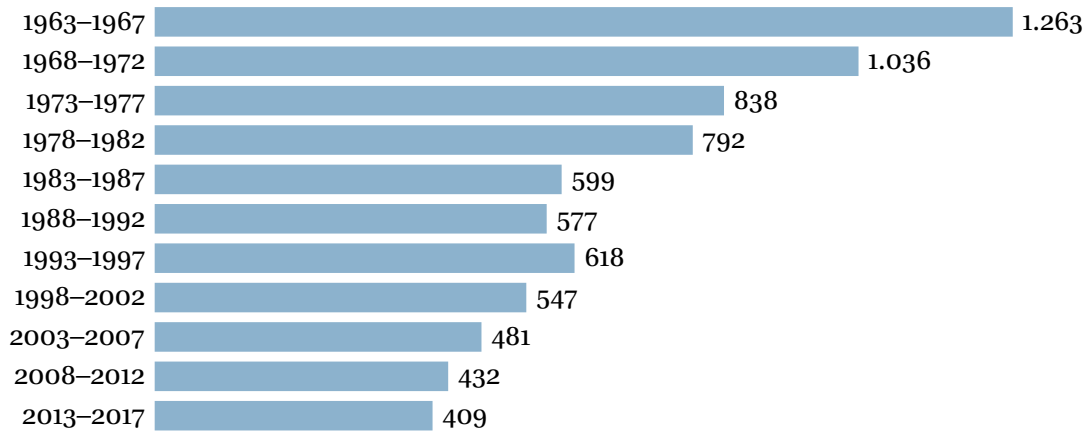

Slika 7.4 Gibanje števila udeležencev na srečanje v obdobju od leta 1963 do 2017 (prirejeno po International Congress and Convention Association, 2018, str. 29)

170

Preglednica 7.3 Gibanje obsega srečanj po regijah

\begin{tabular}{|c|c|c|c|c|c|c|c|c|c|c|c|}
\hline Obm & $\begin{array}{l}1963- \\
1967\end{array}$ & $\begin{array}{l}1968- \\
1972\end{array}$ & $\begin{array}{l}1973- \\
1977\end{array}$ & $\begin{array}{l}1978- \\
1982\end{array}$ & $\begin{array}{l}1983- \\
1987\end{array}$ & $\begin{array}{l}1988- \\
1992\end{array}$ & $\begin{array}{l}1993- \\
1997\end{array}$ & $\begin{array}{l}1998 \\
2002\end{array}$ & $\begin{array}{l}2003 \\
2007\end{array}$ & $\begin{array}{c}2008- \\
2012\end{array}$ & $\begin{array}{l}2013 \\
2017\end{array}$ \\
\hline Evropa & 72 & 67 & 63 & 61 & 59 & 59 & 56 & 55 & 54 & 54 & 54 \\
\hline Azija & 8 & 9 & 10 & 12 & 13 & 14 & 15 & 15 & 17 & 18 & 19 \\
\hline S. Amerika & 13 & 15 & 16 & 17 & 17 & 16 & 16 & 16 & 14 & 13 & 12 \\
\hline J. Amerika & 4 & 5 & 6 & 6 & 6 & 6 & 7 & 8 & 9 & 10 & 10 \\
\hline Afrika & 1 & 2 & 2 & 2 & 2 & 2 & 3 & 3 & 3 & 3 & 3 \\
\hline Oceanija & 1 & 2 & 2 & 2 & 3 & 3 & 4 & 4 & 3 & 3 & 3 \\
\hline Sred. vzhod & o & o & o & o & o & o & o & o & 1 & 1 & 1 \\
\hline
\end{tabular}

Opombe V odstotkih. Prirejeno po International Congress and Convention Association (2018, str. 24).

je bila na drugem mestu Severna Amerika, ko jo je prehitela Azija. Evropa ostaja vodilna kongresna destinacija v svetovnem merilu, saj ima največje število kongresnih mest $\mathrm{z}$ najvišjim številom mednarodnih srečanj. Med prvimi petimi mesti v svetovnem merilu so Pariz, Dunaj, Berlin, London in Barcelona (International Congress and Convention Association, 2018, str. 27).

\section{Posebnosti Slovenije kot destinacije za poslovni turizem}

Začetki kongresne dejavnosti v Sloveniji segajo v 19. stoletje $\mathrm{z}$ organizacijo kongresa Sv. alianse v Ljubljani, vendar za začetek modernega razvoja tega področja velja čas od 50-ih let prejšnjega stoletja dalje. Tedaj se je Slovenija intenzivno razvijala vzporedno z razvojem na ozemlju nekdanje Jugoslavije zaradi vključenosti slednje v gibanje 
neuvrščenih, ki je zahtevalo organizacijo velikega število mednarodnih srečanj (Lucianović, 1980). V Ljubljani je pod okriljem podjetja Magistrat Ljubljana nastal prvi profesionalni kongresni organizator, ki je v letih od 1965 do 1978 organiziral največje kongrese na ozemlju Slovenije. Leta 1971 je bil ustanovljen drugi kongresni oddelek pod okriljem Avditorija Portorož, leta 1978 še tretji na Bledu, ki je deloval v okviru turistične agencije Generalturist. Leta 1986 je bila na prav tako na Bledu ustanovljena kongresna agencija Albatros, ki deluje še danes (Zidanski, 2005).

V prejšnjem poglavju smo videli, da v Sloveniji najdemo vse pomembnejše ponudnike kongresnih storitev, med katerimi prevladuje ponudba prizorišč. V letu 2015 smo v Sloveniji identificirali dobrih 200 različnih prizorišč, med katerimi prevladujejo hoteli s konferenčnimi zmogljivostmi, najmanj pa je kongresnih centrov, zgolj dva. Največ krajev z evidentiranimi prizorišči je v osrednjeslovenski regiji (Ljubljana) in na Gorenjskem, tesno jima sledi Portorož (Sikošek idr., 2014; Sikošek, 2017).

Raziskava o posebnostih Slovenije kot kongresne destinacije (Sikošek, 2017), opravljena med udeleženci srečanj in ponudniki storitev, je pokazala, da ti najbolj cenijo naslednje atribute prometno dostopnost in lokalne povezave, varnost destinacije, odnos domačinov do gostov, urejenost lokalne infrastrukture, ugled destinacije pri strokovni javnosti, kot manj pomembne pa so se izkazale znamenitosti in zanimivosti na destinaciji.

V okviru strategije razvoja turizma v Sloveniji do leta 2021 (Ministrstvo za gospodarski razvoj in tehnologijo, 2017) so poslovna srečanja opredeljena kot nosilni produkt v vseh slovenskih makrodestinacijah, kar pomeni, da so osrednjega pomena za obseg potrošnje in prepoznavnost destinacije, prav tako pa imajo prepoznan potencial za nadaljnjo rast.

Kongresni urad Slovenije kot osrednja institucija za trženje in promocijo Slovenije kot kongresne destinacije oblikuje blagovno znamko Slovenia Meetings. V njej opredeljuje štiri temeljne kongresne produkte na štirih destinacijah: srečanja $v$ mestih, $v$ alpskem in predalpskem svetu, v slovenskih termah in na Obali in Krasu. V letu 2018 je vpeljal marketinški projekt "4 krat 4 Slovenija«, v katerem predstavlja štiri kongresne produkte $\mathrm{v}$ štirih destinacijah preko šestnajstih zgodb (https://www.slovenia-convention.com). Leta 2019 je s projektom nadaljeval tako, da je zgodbam o slovenskih kongresnih de- 
stinacijah dodal nove o iskrivih prostorih. Z njimi opisuje različna unikatna prizorišča za organizacijo poslovnih srečanj v Sloveniji, kot so gradovi, repnice, skladišča soli, konjeniški park, vodni stolp, muzeji, cerkve, gledališča, glampingi, in ideje za oblikovanje kongresnih produktov, povezanih s slovenskim izročilom in posebnostmi slovenskega prostora.

V Sloveniji je mogoče organizirati vse tipe poslovnih srečanja $v$ vseh njenih regijah, vendarle pa so najbolj poznane destinacije Ljubljana, Portorož in Bled, ki imajo najdaljšo kongresno tradicijo. Poleg njih se srečanja odvijajo tudi v Mariboru in drugih manjših krajih ter termalnih zdraviliščih.

\section{Zaključek}

Osnovni motiv poslovnih potovanj izhaja iz opravljanja posameznikovih aktivnosti, vezanih na njegovo zaposlitev in opravljanje dela, iz potrebe po izmenjavi pogledov, izkušenj in znanja, iz potrebe po tkanju poslovnih stikov in profesionalne socialne mreže. Poslovna potovanja pomenijo srečevanja posameznikov na določenem kraju zaradi poslovnih motivov, pri čemer so ta potovanja lahko manj ali bolj številčna. Imenujemo jih poslovni turizem, ki ga glede na številčnost udeležbe ločujemo na individualni in skupinski. Srečevanje posameznikov v večjem številu na določenem prizorišču in destinaciji označujemo kot poslovni turizem v ožjem pomenu, pa tudi kot kongresni turizem, najširše pa je v literaturi in praksi sprejet koncept, ki ga označujemo z akronimom MICE. Ta v sebi združuje štiri temeljne tipe srečanj, zato ga pogosto definiramo tudi kot poslovna srečanja.

$\mathrm{Z}$ opredeljevanjem koncepta se $\mathrm{v}$ raziskovanju in strokovni praksi srečujemo s kar nekaj izzivi glede tega, kako poimenovati posamezne vrste srečanj in kako, če sploh, iz njih izhajajoč opredeliti ta segment turizma. Ko govorimo o posebnih oblikah turizma, ki jih določajo posebni motivi za potovanja, smo potovanja iz poslovnih razlogov opredelili kot poslovni turizem. Vendar pa je, najverjetneje prav zaradi poimenovanja, ki izhaja iz pretežno angleško pišočega okolja, nastalo kar nekaj različnih poimenovanj krovnega pojma, kot so MICE, poslovne prireditve (angl. business events), poslovna srečanja (angl. business meetings), industrija srečanj (angl. meetings industry) ali kongresna industrija (angl. convention/conference/congress industry). 
Dejstvo je, da poslovna srečanja ne glede na tip predstavljajo prostor in priložnost za izmenjavo idej in znanja, s čimer generirajo nova ter s tem dajejo možnosti za razvoj družbe, kar nam kažejo tudi primeri iz zgodovine poslovnih srečanj. Obenem poslovna srečevanja ustvarjajo turistični obisk destinacije in pomenijo prispevek $\mathrm{k}$ turističnemu prometu. Čeprav je bilo v zgodovini srečanj kar nekaj vzponov in padcev, potreba ljudi po srečevanju ne bo zamrla. Lahko se bo spremenil način glede na spremembe v družbi in okolju, saj se srečanjem v klasični obliki pridružujejo njihove virtualne izpeljanke, vendar pa ljudje čutimo nenehno potrebo po medsebojni interakciji, ki jo je mogoče uresničiti zgolj v obliki medsebojnih, predvsem fizičnih srečanj.

\section{Literatura}

Burkart, A. J., in Medlik, S. (1992). Tourism: Past, present and future. Butterworth-Heinemann.

Cassar, J., Whitfield, J., in Chapman, A. (2020). Contemporary factors influencing association conference attendance. Journal of Convention \& Event Tourism, 21(1), 57-90.

Crouch, G. I., in Louviere, J. J. (2004). The determinants of convention site selection: Alogistic choice model from experimental data. Journal of Travel Research, 43(2), 118-130.

Davidson, R., in Rogers, T. (2006). Marketing destinations and venues for conferences, conventions and business events. Routledge.

DiPietro, R. B., Breiter, D., Rompf, P., in Godlewska, M. (2008). An exploratory study of differences among meeting and exhibition planners in their destination selection criteria. Journal of Convention \& Event Tourism, 9(4), 258-276.

Dragićević, V., Armenski, T., in Jovićić, D. (2009). Analyses of the competitiveness of Novi Sad as a regional congress destination. Tourism and Hospitality Management, 15(2), 247-256.

Fenich, G. G. (1995). Convention center operations: Some questions answered. International Journal of Hospitality Management, 14(3), 311324.

Ford, R. C. (2008). Chasing MICE and fellow travelers: A history of the convention and visitor bureau industry. Journal of Management History, 14(2), 128-143.

Getz, D., in Page, S. J. (2016). Progress and prospects for event tourism research. Tourism Management, 52, 593-631.

Huo, Y. (2014). Meeting planners' perception on convention destination attributes: empirical evidence from six major Asian convention cities. Journal of Business Inquiry, 13(2), 70-80. 
International Congress and Convention Association. (2018). A modern history of international association meetings: Update 1963-2017 [brošura]. https://www.iccaworld.org/dcps/doc.cfm?docid=2274

Jago, L., in Deery, M. (2005). Relationships and factors influencing convention decision-making. Journal of Convention and Event Tourism, 7(1), 23-41.

Jago, L., in Deery, M. (2010). Delivering innovation, knowledge and performance: The role of business events. Business Events Council of Australia.

Ladkin, A. (2002). Research issues and challenges for the convention industry. V K. Weber in K. S. Chon (ur.), Convention tourism: International research and industry perspectives (str. 101-118). The Haworth Hospitality.

Ladkin, A. (2006). Conference tourism - MICE market and business tourism. V D. Buhalis in C. Costa (ur.), Tourism business frontiers: Sonsumers, products and industry (str. 56-66). Elsevier ButterworthHeinemann.

Lee, R. A. J. (2020, 2. januar). The pleasure of bleisure. TTGmice. http:// www.ttgmice.com/2020/o1/o2/the-pleasure-of-bleisure/

Lucianović, L. (1980). Kongresni turizam. Svjetlost.

Mair, J. (2013). Conferences and conventions: A research perspective. Routledge.

Mair, J., in Thompson, K. (2009). The UK association conference attendance decision-making process. Tourism Management, 30(3), 400409.

Ministrstvo za gospodarski razvoj in tehnologijo. (2017). Strategija trajnostne rasti slovenskega turizma 2017-2021 [brošura]. https://www .slovenia.info/uploads/dokumenti/kljuni_dokumenti/strategija _turizem_koncno_9.10.2017.pdf

Mohammadi, A. M., in Mohamed, B. (2011). Applying consumer behaviour theory and grand models to attendees behaviour in coference industry. Tourism \& Management Studies, 1, 151-159.

Oppermann, M. (1996a). Convention cities - Images and changing fortunes. The Journal of Tourism Studies, 7(1), 10-19.

Oppermann, M. (1996b). Convention destination images: Analysis of association meeting planners' perceptions. Tourism Management, 17(3), 175-182.

Oppermann, M., in Chon, K.-S. (1997). Convention participation decisionmaking process. Annals of Tourism Research, 24(1), 178-191.

Rittichainuwat, B., in Mair, J. (2012). Motivations for attending consumer shows. Tourism Management, 33, 1236-1244.

Rogers, T. (1998). Conferences: A twenty-first century industry. Adison Wesley Longman. 
Rogers, T. (2008). Conferences and conventions: A global industry. Routledge.

Seekings, D. (1992). How to organize effective conferences and meetings. Kogan Page.

Shone, A. (1998). The business of conferences: A hospitality sector overview for the $\mathrm{U} \mathrm{K}$ and Ireland. Routledge.

Sikošek, M. (2012). A review of research in meetings management: Some issues and challenges. Academica Turistica, 5(2), 61-76.

Sikošek, M. (2017). Kongresna dejavnost: vidiki privlačnosti destinacije. Založba Univerze na Primorskem.

Sikošek, M., Bojnec, Š., Fabjan, D., in Uran Maravić, M. (2014). Obseg dejavnosti in neposredni ekonomski učinki kongresnega turizma v Sloveniji: primer Ljubljana [zaključno poročilo]. Javna agencija SPIRIT Slovenija.

Slovar slovenskega knjižnega jezika. (2014). Založba zRc. http://www .fran.si

Slovenian Convention Bureau. (2014). Slovenian incentive ideas book [brošura].

Spiller, J. (2002). History of convention tourism. V K. Weber in K. S. Chon (ur.), Convention tourism: International research and industry perspectives (str. 3-20). The Haworth Hospitality.

Swarbrooke, J., in Horner, S. (2001). Business travel and tourism. Butterworth-Heinemann.

Turizem Ljubljana. (2011). Kongresna Ljubljana 2020: razvojna politika kongresne destinacije Ljubljana 2012-2020. https: / www .visitljubljana.com/assets/Dokumenti-PDF/O-turizmu-LJ/ kongresna-politika-ljubljana-2020.pdf

Weber, K., in Chon, K. S. (2002). Convention tourism: International research and industry perspectives. The Haworth Hospitality.

World Tourism Organization. (2006). Measuring the economic importance of the meetings industry: Developing a tourism satellite account extension.

Zidanski, M. (2005). Kongresna dejavnost: organizacija kongresov. Albatros. 